\title{
IMPLEMENTASI TOTAL QUALITY MANAGEMENT (TQM) DI LEMBAGA PENDIDIKAN
}

\author{
Oleh: Feiby Ismail
}

\begin{abstract}
Abstrak
Implementasi Total Quality Management (TQM) perlu dilakukan pada lembaga pendidikan sebagai bentuk dari upaya peningkatan kualitas pendidikan. Hal ini penting untuk menjalankan fungsi manajemen dalam setiap lembaga pendidikan. Kajian ini membahas tentang implementasi total quality management (TQM) di lembaga pendidikan serta upaya peningkatan mutu pendidikan dalam mencapai standar mutu yang telah ditentukan. Setiap lembaga pendidikan sudah seharusnya menunjukkan kualitas yang lebih baik. Hal ini dimaksudkan agar lembaga pendidikan tetap mendapatkan kepercayaan masyarakat dan stakeholder. Salah satu cara untuk tetap mendapatk hal tersebut adalah dengan melakukan perbaikan secara berkelanjutan (continous improvement), baik dari aspek fisik maupun non fisik. Sehingga menjadi lembaga pendidikan yang bermutu dan terjamin kualitasnya. Ada beberapa hal pokok yang perlu diperhatikan dalam penerapan TQM di dunia pendidikan, yaitu: perbaikan secara terus menerus (continous improvement); menentukan Standar Mutu, (Quality assurance); perubahan kultur (change of culture); perubahan organisasi (upsidedown-organization); dan mempertahankan hubungan dengan pelanggan (keeping close to the customer). Implementasi TQM perlu ditunjang dengan strategi pelaksanaan yang baik serta kerjasama seluruh elemen sekolah.

Kata Kunci: Implementasi, TQM, Manajemen, Pendidikan.
\end{abstract}

\section{Pendahuluan}

Kondisi dunia yang semakin maju dan berkembang menuntut adanya persiapan yang matang bagi semua manusia untuk masuk di dalamnya. Berbagai tantangan dunia telah memberikan sinyal bahwa Indonesia sebagai anggota dunia harus mampu menghadapi berbagai tantangan yang muncul sebagai akibat dari perkembangan zaman dan globalisasi yang semantara berjalan. Selain globalisasi, perkembangan teknologi informasi juga menjadi tantangan besar bagi bangsa Indonesia, tanpa ada upaya yang baik untuk memfilter dengan baik maka Indonesia akan terbawa dengan arus globalisasi tanpa arah. Oleh sebab itu, pendidikan perlu dijadikan kekuatan untuk membentengi manusia Indonesia dengan kualitas iman taqwa serta ilmu pengetahuan dan teknologi.

Perkembangan zaman yang ditandai dengan perkembangan ilmu pengetahuan dan teknologi, semakin menuntut peningkatan kualitas pendidikan dalam berbagai aspek. Peningkatan tersebut tidak hanya pada satu aspek saja, akan tetapi mencakup segala aspek yang berkaitan dalam proses pendidikan mulai dari masukan (input), proses dan keluaran (output). Salah satu tolak ukur peningkatan tersebut ada pada perbaikan aspek manajemen yang baik. Apabila manajemen sudah diterapkan dengan baik maka institusi apapun termasuk 
institusi pendidikan akan mampu menghasilkan kinerja dan hasil karya yang bermutu. Menurut Fattah, manajemen mempunyai peran atau membantu menjelaskan prilaku organanisasi yang berkaitan dengan motivasi, produktivitas, dan kepuasan (satisfaction). ${ }^{1}$ Hal ini menunjukkan bahwa manajemen memiliki peran penting untuk mengantarkan kemajuan organisasi.

Oleh karena itu, persoalan manajemen perlu mendapat perhatian karena memberikan implikasi pada peningkatan mutu pendidikan itu sendiri. Dalam dunia bisnis dan industri dikenal istilah Total Quality Management (TQM) yang kemudian diadopsi dalam dunia pendidikan. Ada yang tetap menggunakan istilah yang sama yaitu Total Quality Management (TQM), ada pula yang melakukan penyesuaian dengan istilah Total Quality Education (TQE). Apapun istilah yang digunakan namun ujung dari penerapan istilah tersebut adalah peningkatan kualitas atau aspek mutu yang semakin baik dari pengelolaan sebuah insitusi baik bisnis, industri maupun juga pendidikan.

\section{Pembahasan}

Dalam dunia pendidikan, peningkatan kualitas dan mutu pendidikan akan sangat ditentukan oleh banyak aspek, seperti guru, staf, siswa, kurikulum, proses belajar mengajar, dukungan pembiayaan, pengelolaan, dan masih banyak lagi. Namun bila dikategorikan dalam dua aspek besar yaitu aspek internal dan eksternal. Internal menyangkut keseluruhan komponen dalam sekolah sedangkan aspek internal merupakan aspek yang berasal dari luar yang menunjang dan menentukan keberhasilan pendidikan di sebuah institusi. Keduanya akan saling menopang dan menunjang dalam mencapai tujuan pendidikan.

Pengelolaan sekolah yang baik dan bermutu akan ditentukan dengan seberapa besar dukungan yang diberikan oleh lingkungan, masyarakat, dan pemerintah dalam menunjang kegiatan pendidikan. Demikian pula dengan keberhasilan program pemerintah dan masyarakat dalam pendidikan harus ditopang penuh oleh kesiapan guru, staf dan siswa dalam menjalankan amanah pendidikan yang ditentukan dalam Undang-undang.

Dalam hal mutu dan kualitas pendidikan terdapat suatu standar yang ditentukan dalam standar nasional pendidikan. Standar nasional yang ditetapkan merupakan standar yang sudah dikaji dan dapat dicapai oleh setiap lembaga pendidikan di Indonesia. Konsep tentang standarisasi pendidikan nasional berimplikasi pada peningkatan mutu pendidikan, sehingga diharapkan dengan adanya standar nasional dapat memotivasi sekolah untuk memberikan layanan yang terbaik bagi peserta didik di lingkungan pendidikannya.

\footnotetext{
${ }^{1}$ Nanang Fatah, Landasan Manajemen Pendidikan (Bandung: Remaja Rosdakarya, 2001), h.11.
} 
Isu aktual tentang pendidikan sesungguhnya adalah wilayah dari semua proses pendidikan yang meliputi proses pendidikan dari awal sampai akhir dalam upaya untuk mencapai tujuan pendidikan yang bermutu dan berkualitas tinggi. Mutu tidak hanya menjadi sebuah harapan dan cita-cita namun harus menjadi suatu target riil yang harus dicapai dalam rangka peningkatan kualitas secara berkelanjutan (continous improvement). Untuk itu, M. Qomar menyatakan beberapa hal yang mulai dilakukan pemerintah Indonesia saat ini dalam mengupayakan berbagai cara untuk meningkatkan mutu pendidikan dengan berbagai upaya seperti penyesuaian, dan penyempurnaan kurikulum, perbaikan dan penataan sistem pendidikan secara berjenjang pada semua jalur pendidikan, peningkatan kualitas proses pembelajaran, termasuk dalam hal kesejahteraan pendidik, saran dan prasarana pendidikan serta standar evaluasi yang baik, membangun fasilitas pendidikan, menetapkan standar nasional pendidik, menggunakan sistem penjamin mutu, memperketat akreditasi dan masik banyak lagi. ${ }^{2}$ Permasalahan mutu sangat penting bagi sebuah lembaga pendidikan untuk menghasilkan output yang baik, sebab semakin bermutu lulusan yang dihasilkan maka nilai jual dan ketertarikan untuk masuk ke lembaga pendidikan tersebut semakin meningkat. Sebaliknya jika mutu rendah maka mutu lulusan rendah yang berdampak pada rendahnya minat dan daya serap masuk ke lembaga pendidikan.

\section{A. TQM dan Tantangan Pendidikan Indonesia}

TQM atau total quality management adalah suatu makna dan standar mutu dalam pendidikan. Ia memberikan suatu filosofi perangkat alat untuk memperbaiki mutu. Ia dicapai dengan ide sentral yang diwujudkan dalam bentuk pelaksanaan. ${ }^{3}$ Bagi setiap lembaga pendidikan mutu adalah suatu isu sentral yang perlu diperhatikan. Memang akan terkesan cenderung ke dunia bisnis dan industri bila mendengar istilah TQM, namun pada kenyataannya beberapa lembaga pendidikan sudah mulai menerapkan standar mutu tertentu dengan istilah Manajemen Mutu Terpadu.

TQM menginginkan adanya peningkatan (improvement) dalam berbagai hal. Oleh karenanya, meningkatnya kualitas/mutu menjadi titik utama dalam manajerial serta bahasan tentang TQM. Juran mendemonstrasikan tiga proses manajerial suatu organisasi yang dikenal dengan trilogy Juran yaitu, Planning, control, improvement. Adapun rincian trilogy itu sebagai berikut :

\footnotetext{
${ }^{2}$ Mujamil Qomar, Kesadaran Pendidikan; Sebuah Penentu Keberhasilan Pendidikan, (Yogyakarta: Arruzz Media, 2012), Cet.1, h. 48.

${ }^{3}$ Edward Sallis, Total Quality Management in Education, Manajemen Mutu Pendidikan Jogjakarta:
} IRCiSoD, 2006), h. 23. 
- Quality planning, suatu proses yang mengidentifikasi pelanggan dan proses yang akan menyampaikan produk dan jasa dengan karakteristik yang tepat dan kemudian mentransfer pengetahuan ini ke seluruh kaki tangan perusahaan guna memuaskan pelanggan.

- Quality control, suatu proses dimana produk benar-benar diperiksa dan dievaluasi, dibandingkan dengan kebutuhan-kebutuhan yang diinginkan para pelanggan. Persoalan yang telah diketahui kemudian dipecahkan, misalnya mesin-mesin rusak segera diperbaiki.

- Quality improvement, suatu proses dimana mekanisme yang sudah mapan dipertahankan sehingga mutu dapat dicapai berkelanjutan. Hal ini meliputi alokasi sumber-sumber, menugaskan orang-orang untuk menyelesaikan proyek mutu, melatih para karyawan yang terlibat dalam proyek mutu dan pada umumnya menetapkan suatu struktur permanen untuk mengejar mutu dan mempertahankan apa yang telah dicapai sebelumnya ${ }^{4}$.

Meskipun konsep tersebut cenderung pada pengelolaan keuangan atau finansial, namun dapat diterjemahkan dalam berbagai bidang termasuk pendidikan. Intinya adalah bahwa adanya penekanan tentang pentingnya perbaikan mutu secara terus menerus bagi setiap produk walaupun teknik yang diajarkan berbeda-beda.

Dalam dunia bisnis, mutu adalah kepuasan pelanggan, bila diterjemahkan dalam dunia pendidikan adalah kepuasan masyarakat (stakeholders) terhadap output dari lembaga pendidikan itu sendiri. TQM merupakan perluasan dan pengembangan dari jaminan mutu. TQM adalah tentang usaha menciptakan sebuah kultur mutu, yang mendorong semua anggota stafnya untuk memuaskan para pelanggan. ${ }^{5}$ Dengan demikian, upaya yang dilakukan dalam pendidikan adalah menjamin mutu pendidikan agar masyarakat dan stakeholders lainnya yang relevan akan mendapatkan kepuasan hasil dari sebuah proses pendidikan di lembaga pendidikan tertentu. Tentu saja, masyarakat dan dunia luar tidak memikirkan bagaimana prosesnya, akan tetapi mereka mengharapkan setiap output dari lembaga-lembaga pendidikan dapat menyesuaikan dengan kebutuhan-kebutuhan yang ada di masyarakat.

Strategi yang dikembangkan dalam penggunan manajemen mutu terpadu dalam dunia pendidikan adalah institusi pendidikan memposisikan dirinya sebagai institusi jasa atau dengan kata lain menjadi industri jasa yakni institusi yang memberikan pelayanan (service)

\footnotetext{
${ }^{4}$ http://guruidaman.blogspot.co.id/2014/06/total-quality-management-dalam.html

${ }^{5}$ Edward Sallis, op.cit. h. 59.
} 
sesuai dengan apa yang diinginkan oleh pelanggan (customer). Setiap pelanggan tentu saja menginginkan pelayanan yang memuaskan, sehingga institusi harus mampu meningkatkan pelayanan dan mutu jasa mereka. Oleh karena itu, perlu sistem manajemen mutu yang mampu memberdayakan institusi pendidikan agar lebih bermutu. ${ }^{6}$

Nasution dalam Manajemen Mutu Terpadu mengatakan bahwa TQM merupakan sistem manajemen uang berfokus pada semua orang/tenaga kerja, bertujuan untuk terus menerus meningkatkan nilai yang diberikan bagi pelanggan. TQM memerlukan komitmen semua anggota organisasi terhadap perbaikan seluruh aspek manajemen organisasi. ${ }^{7}$ Dengan demikian, untuk mewujudkan suatu manajemen mutu terpadu tidak dapat dilakukan oleh satu atau dua orang saja melainkan harus melibatkan seluruh komponen dalam organisasi atau institusi.

Bila melihat dalam sebuah institusi pendidikan, maka sekolah, guru, staf administrasi, siswa dan komponen lainnya harus bekerja sama dalam mewujudkan manajemen mutu terpadu di lingkungan sekolahnya dengan tujuan peningkatan kualitas dan mutu baik dalam pelayanan pendidikan maupun dalam menghasilkan lulusan yang berkualitas. Pada kenyataannya, dunia pendidikan di Indonesia masih berkutat pada tataran perencanaan dan pergulatan kurikulum yang seperti tidak ada habisnya. Perbedaan konsep dan sudut pandang tentang tujuan pendidikan nasional dan upaya implementasinya terkadang menjadi jurang pemisah pemikiran yang besar di antara para ahli pendidikan di negeri ini dalam melahirkan sumber daya manusia yang mampu bersaing secara global. Tuntutan akan adanya kualitas dan mutu pendidikan yang baik semakin besar dengan iptek yang semakin maju, seperti penguasaan IT, baik bagi peserta didik maupun pendidik dalam proses pembelajaran yang aktif, kreatif, inovatif dan menyenangkan serta tenaga administrasi dalam peningkatan layanannya, sehingga membuat penyesuaian dalam model dan strategi pembelajaran dengan pendekatan teknologi informasi. Sementara di sisi lain, kemajuan ini mengancam nilai-nilai sosial budaya dan keagamaan manusia Indonesia.

Tentu saja kecenderungan konsentrasi perbaikan terhadap mutu dalam proses pendidikan sangat penting untuk dikedepankan, sebab berbicara tentang mutu tidak sematamata berkaitan dengan input, proses, dan output, akan tetapi juga outcome. Apabila input pendidikan yang bermutu berkaitan dengan pendidik, staf administrasi, peserta didik, kurikulum, sarana dan prasarana serta elemen lain dalam penyelenggaraan pendidikan.

\footnotetext{
${ }^{6}$ Edward Sallis, op.cit. h. 6.
}

${ }^{7}$ M.N. Nasution, Manajemen Mutu Terpadu (Bogor: Ghalia IKAPI, 2005), h. 28. 
Kemudian proses adalah upaya mengembangkan semua masukan dan potensi peserta didik dalam program pembelajaran yang sudah ditetapkan. Maka output yang bermutu adalah menyangkut lulusan yang memiliki kompetensi yang memadai sesuai dengan tujuan yang telah ditetapkan. Sedangkan outcome yang bermutu adalah lulusan yang mampu melanjutkan ke jenjang pendidikan yang lebih tinggi, sebagai bentuk dari implementasi input dan proses pendidikan.

Salah satu cara yang dapat ditempuh yaitu dengan menerapkan atau mengimplementasikan TQM dalam pendidikan sebagai salah satu cara untuk mencapai tujuan-tujuan pendidikan yang telah ditetapkan dalam Undang-Undang Sistem Pendidikan Nasional Nomor 20 tahun 2003. Untuk mencapai tujuan tersebut, perlu adanya pembenahan dalam hal pengelolaan pendidikan, penerapan manajemen berbasis sekolah, dan upaya lainnya menuju perbaikan menyeluruh dalam pendidikan agar mampu menjawab tuntutan mutu pendidikan sesuai standar nasional pendidikan.

\section{B. Implementasi TQM dalam Pendidikan}

Kata implementasi berarti penerapan; penggunaan implemen dalam kerja; pelaksanaan; pengerjaan hingga menjadi terwujud; pengejawantahan; dan penerapan implemen. ${ }^{8}$ Sedangkan TQM (Total Quality Management) menurut Hardjosoedarmo memberikan pengertian yang cukup menyeluruh, bahwa TQM adalah penerapan metode kuantitatif dan pengetahuan kemanusiaan untuk: 1) memperbaiki material dan jasa yang menjadi masukan organisasi, 2) memperbaiki semua proses penting dalam organisasi, dan 3) memperbaiki upaya memenuhi kebutuhan para pemakai produk dan jasa pada masa kini dan waktu yang akan datang. ${ }^{9}$

Sementara itu, menjelaskan bahwa TQM adalah satu himpunan prinsip-prinsip, alatalat dan prosedur-prosedur yang memberikan tuntunan dalam praktik penyelenggaraan organisasi. TQM melibatkan seluruh anggota organisasi dalam mengendalikan dan secara kontinu meningkatkan bagaimana kerja harus dilakukan dalam upaya mencapai harapan pengguna atau pelanggan (customer) mengenai mutu produk atau jasa yang dihasilkan organisasi. ${ }^{10}$ Dari beberapa pengertian ini, dapat dipahami bahwa Implementasi Total Quality Management (TQM) adalah penerapan atau pengejawantahan konsep manajemen yang

\footnotetext{
${ }^{8}$ Tim Gama Jakarta, Kamus Saku Ilmiah Populer, (Jakarta: Gama Press, 2010), Cet.1, h. 278.

${ }^{9}$ Soewarso Hardjosoedarmo, Total Quality Manajemen, (Yogyakarta: Penerbit Andi, 2004), h. 1.

10 Veithrizal Rivai, Education Management; Analisis Teori dan Praktik, (Jakarta: Raja Grafindo
} Persada: 2009), h. 479. 
melibatkan seluruh komponen dalam organisasi untuk bersama-sama berkontribusi dalam kebijakan organisasi yang berorientasi pada perbaikan mutu produk untuk kepuasan pelanggan (customer).

Dalam dunia pendidikan, TQM mengarahkan pada kepuasan pelanggan baik pelanggan dalam (internal customer) maupun pelanggan luar (eksternal customer). Pelanggan dalam seperti kepala sekolah, guru, staf dan penyelenggara institusi. Sedangkan pelanggar luar seperti masyarakat, pemerintah dan dunia industri. Jadi suatu institusi atau lembaga pendidikan dikatakan bermutu apabila mampu memberikan kepuasan terhadap pelanggan dalam dan pelanggan luar atas jasa yang diberikan.

Ada beberapa hal pokok yang perlu diperhatikan dalam penerapan TQM di dunia pendidikan, yaitu:

1. Perbaikan secara terus menerus (continous improvement). Konsep ini mengandung pengertian bahwa pihak pengelola senantias melakukan berbagai perbaikan dan peningkatan terus menerus untuk menjamin semua komponen penyelenggaraan pendidikan telah mencapai standar mutu yang ditetapkan. Konsep ini juga berarti bahwa institusi pendidikan senantiasa memperbaharui proses berdasarkan kebutuhan dan tuntutan.

2. Menentukan Standar Mutu, (Quality assurance). Paham ini digunakan untuk menentukan standar-standar mutu dari semua komponen yang bekerja dalam proses produksi atau tranformasi lulusan institusi pendidikan. Standar ini meliputi kepemilikan kemampuan dasar pembelajaran sesuai dengan jenjang pendidikan, kurikulum, dan evaluasi.

3. Perubahan Kultur (change of culture). Pimpinan institusi pendidikan harus mampu membangun kesadaran para anggotanya akan pentingnya mempertahankan dan meningkatkan mutu pembelajaran.

4. Perubahan Organisasi (upside-down-organization). Penerapannya dalam lingkungan sekolah bisa terlaksana dalam bentuk perubahan struktur organisasi sekolah dalam manajemen berbasis sekolah. Awalnya dalam struktur konvensional dari atas ke bawah, maka dalam struktur baru bisa berubahandari bawah ke atas.

5. Mempertahankan hubungan dengan pelanggan (keeping close to the customer). Hubungan yang baik antara institusi pendidikan dengan masyarakat, orang tua siswa 
dan pihak lain, maka institusi atau lembaga pendidikan harus mampu menjalin hubungan yang baik dengan "pelanggannya". 11

Berdasarkan uraian tersebut, berarti sekolah memiliki tanggung jawab yang besar dalam rangka peningkatan mutu secara berkelanjutan. Tanggung jawab tersebut harus diemban tidak hanya oleh kepala sekolah sebagai manajer akan tetapi oleh seluruh komponen untuk menunjang terlaksananya manajemen mutu terpadu di lingkungan sekolahnya. Artinya bahwa keterlibatan seorang pemimpin sebagai manajer dalam organisasi yang dipimpinnya dalam hal ini kepala sekolah di lingkungan sekolah sangat memberikan peran dalam upaya peningkatan mutu pendidikan.

Salah satu konsep dari Edward Deming yang selanjutnya lebih dikenal dengan konsep kaizen secara luas baru diperkenalkan oleh Masaaki Imai dalam bukunya "Kaizen : the key to Japan's competitive success" (1986). Kesimpulan Europe Japan Centre tentang Kaizen Jepang mengungkapkan bahwa:

"Kaizen mengatakan kepada kita bahwa hanya dengan secara terus menerus tetap sadar dan membuat beratus-ratus ribu peningkatan kecil, maka dimungkinkan untuk menghasilkan barang dan jasa yang mutunya otentik sehingga memuaskan pelanggan. Cara paling mudah mencapainya adalah dengan keikutsertaan, motivasi dan peningkatan terus menerus dari masing-masing dan semua karyawan dalam organisasi. Keikutsertaan staf tergantung pada komitmen manajemen senior, strategi yang jelas dan ketabahan - karena kaizen bukan jalan pintas melainkan proses yang berjalan secara terus menerus untuk menciptakan hasil yang diinginkan". (Cane, 1998:265) dalam http://guruidaman.blogspot.co.id/2014/06/total-qualitymanagement-dalam.html.

Hal ini berarti bahwa tanpa keterlibatan pimpinan secara aktif tidak mungkin tercapai manajemen mutu terpadu. Dalam perjalanan manajemen mutu ini muncul juga istilah manajemen berbasis sekolah (MBS) yang mengacu pada manajemen sumber daya di tingkat sekolah dan bukan di suatu sistem atau tingkat sentralistik atau terpusat. Melalui MBS beberapa sekolah diberikan pengawasan lebih besar, pengelolaan anggaran dan pengembangan staf, sampai pada aspek kurikulum berbasis sekolah yang berarti bahwa masing-masing sekolah memutuskan bahan-bahan ajar apa yang akan digunakan. ${ }^{12}$

Kemampuan sekolah untuk menjalankan suatu manajemen yang baik akan sangat bergantung pada kesiapan dan kemampuan setiap komponen dalam menjalankan tugasnya pada bidang masing-masing. Terkadang manajemen tidak dapat berjalan baik bukan karena

\footnotetext{
${ }^{11}$ Edward Sallis, Op.cit., h. 7-11.

${ }^{12}$ Ibtasam Abu-Duhou, School Based Mangement, Manajemen Berbasis Sekolah (Jakarta: Logos,
} 2002), h. 25 . 
kesalahan dalam implementasi namun karena ketidaksiapan dari komponen pendidikan untuk melaksanakan perannya. Oleh sebab itu, kepala sekolah perlu untuk meninjau kesiapan seluruh komponennya, baik staf, guru, siswa, kurikulum, seluruh sistem yang saling berkaitan dalam mengefektifkan manajemen mutu terpadu.

Ada beberapa pertimbangan yang dijadikan landasan penerapan TQM di lembaga pendidikan. Para pendidik harus bertanggung jawab terhadap tugas mereka secara proaktif. Mereka harus mengembangkan proses pemecahan masalah yang masuk akal dan dapat mengidentifikasi serta menuju pada penyebab utamanya. Sekolah harus mampu menjadi organisasi percontohan dan dapat mengukur apa saja yang berfungsi dengan baik dan apa yang tidak, sehingga akan didapatkan suatu sistem yang baik dalam kelembagaan sekolah. Ada empat alasan utama dalam adopsi TQM di lembaga pendidikan, antara lain: ${ }^{13}$

Pertama, para pendidik harus bertanggung jawab terhadap tugas dan fungsi mereka, karena para pendidik merupakan faktor utama bagi peningkatan sekolah. Para pendidik harus mengendalikan proses penyelesaian masalah yang berdampak pada lingkungan belajar di sekolah.

Kedua, pendidikan membutuhkan proses pemecahan masalah yang peka dan fokus pada identifikasi dan penyelesaian penyebab utama yang menimbulkan masalah tersebut. Semua akar dalam masalah pendidikan bersifat sistemik, yaitu berasal dari akar masalah yang berada dari komunitas sekolah dan berimplikasi pada kegiatan belajar mengajar di sekolah itu sendiri.

Ketiga, organisasi sekolah harus menjadi model organisasi belajar semua organisasi.

Keempat, melalui integrasi TQM di lembaga pendidikan, masyarakat dapat menemukan mengapa sistem pendidikan yang ada saat ini tidak berjalan dengan baik.

Berdasarkan alasan tersebut, jelaslah bahwa penerapan TQM dalam dunia pendidikan merupakan memerlukan adanya pengelolaan yang baik dan profesional, manajemen organisasi yang baik dan penyediaan personil yang memadai dalam menjalankan proses yang baik sehingga menghasilkan output yang bermutu dan berkualitas tinggi.

\section{Strategi Pelaksanaan}

Secara teoretik, penerapan konsep Total Quality Management (TQM) dalam dunia pendidikan khususnya lembaga pendidikan ini dapat diimplementasikan dengan beberapa 483-484.

${ }^{13}$ E. Mulyasa, Menjadi Kepala Sekolah Profesional, Cet. 9, (Bandung: Remaja Rosdakarya, 2007), h. 
fase teoritik sebagaimana klasifikasi yang Goetsch dan Davis (1994), yaitu fase persiapan, fase perencanaan, dan fase pelaksanaan. ${ }^{14}$

1. Fase Persiapan

Fase ini terdiri dari 10 langkah, yang mana sebelum langkah pertama dimulai, syarat utama yang harus dipenuhi adalah adanya komitmen penuh dari manajemen puncak atas waktu dan sumber daya yang dibutuhkan. Langkah-langkahnya antara lain:

a. Membentuk Total Quality Steering Committee (SC). Pimpinan puncak menunjuk staf terdekat (bawahan langsungnya) untuk menjadi anggota steering committee (SC), kemudian ia sendiri menjadi ketuanya.

b. Membentuk Tim. Steering Committee perlu mengadakan suatu sesi pembentukan tim sebelum memulai kegiatan TQM. Biasanya, langkah ini membutuhkan konsultan. Kalau dalam pendidikan, perlu didatangkan dari luar seorang konsultan pendidikan. Lebih baik sesi ini dilakukan di luar lembaga pendidikan. Agar bisa lebih fokus melakukan pembahasan tanpa mengganggu proses KBM (Kegiatan Belajar Mengajar).

c. Pelatihan TQM. SC (Steering Commitee) membutuhkan pelatihan yang berkaitani dengan filosofi, teknik dan alat-alat TQM sebelum memulai aktifitas TQM. Dalam pelatihan ini, perlu mendatangkan pula seorang konsultan. Kemudian pada jangka panjangnya, juga diadakan pelatihan yang serupa sebagai follow up dari pelatihan yang pertama.

d. Menyusun Pernyataan Visi dan Prinsip sebagai Pedoman. Usaha yang pertama dalam TQM adalah penyusunan visi organisasi dan pedoman operasi organisasi.

e. Menyusun Tujuan Umum. SC menyusun tujuan umum dari organisasi (perusahaan atau sekolah) berdasarkan pernyataan visi yang telah ditetapkan.

f. Komunikasi dan Publikasi. Pemimpin puncak dan SC perlu mengkomunikasikan setiap informasi mengenai visi dan misi, prinsip-prinsip sebagai pedoman, tujuan dan konsep TQM.

g. Identifikasi Kekuatan dan Kelemahan. SC harus secara obyektif mengidentifikasi kekuatan dan kelemahan organisasi. Ini sangat penting untuk mencari pendekatan terbaik dalam pelaksanaan TQM dan bisa untuk menyoroti kekurangan-kekurangan yang harus diperbaiki. Kemudian melakukan perbaikan-perbaikan strategis ke depannya.

h. Identifikasi Pendukung dan Penolak. Langkah ini di dorong ni bisa dilakukan bersamaan dengan langkah identikasi kelemahan dan kekuatan atau sesudahnya. Di sini, SC h. 67 .

${ }^{14}$ Fandy Tjiptono dan Anastasia Diana, Total Quality Management, (Yogyakarta: Andi Offset, 2003), 
mengidentifikasi orang-orang kunci yang mungkin menjadi penolak dan pendukung TQM. Terutama untuk anggota penolak TQM, ini dimungkinkan terjadi, karena ada kemungkinan orang tersebut belum paham dan siap dengan konsep TQM yang telah dijalankan. Dalam hal ini perlu dicari akar permasalahannya dan diadakan langkahlangkah untuk meminimalisirnya.

i. Memperkirakan Sikap Karyawan. Dengan bantuan personalia atau konsultan luar, SC perlu berusaha memperkirakan sikap karyawan pada saat ini. Pimpinan perlu memberikan judgment yang obyektif. Jika itu sudah dilakukan, akan dapat diketahui apakah TQM berjalan atau tidak.

j. $\quad$ Mengukur Kepuasan Pelanggan. SC perlu berusaha mendapatkan umpan balik obyektif dari para pelanggan guna menentukan tingkat kepuasan mereka. Survai kepada pelanggan sebaiknya dilakukan secara acak.

2. Fase Perencanaan

Dalam fase ini ada empat (4) langkah yang harus dijalani secara sistematis. Karena semuanya membentuk sistem yang saling mempengaruhi. Adapun langkah-langkahnya adalah:

a. Merencanakan pendekatan implementasi, kemudian menggunakan siklus PDCA (PlanDo - Check - Adjust). Pada langkah ini, SC merencanakan implementasi TQM. Langkah ini bersifat terus-menerus, karena pasa saat aktivitas pembelajaran berlangsung, informasi -informasi umpan balik akan dikembalikan pada langkah ini untuk melakukan perbaikan, peyesuaian, dan sebagainya.

b. Identifikasi Poyek. SC bertanggung jawab untuk memilih proyek atau program kegiatan awal TQM, yang didasarkan pada kekuatan dan kelemahan perusahaan, personil yang terlibat, visi dan tujuan, dan kemungkinan keberhasilannya.

c. Komposisi Tim. Steering Committee membentuk komposisi tim-tim yang akan melaksanakan program TQM tersebut.

d. Pelatihan Tim. Sebelum tim yang baru terbentuk untuk melaksanakan tugasnya, mareka harus dilatih terlebih dahulu. Pelatihan yang diberikan harus mencakup dasar-dasar TQM dan instrumen yang sesuai untuk melaksanakan program kegiatan yang akan mereka laksanakan.

3. Fase Pelaksanaan

a. Penggiatan Tim. Steering Committee memberikan bimbingan kepada setiap tim dan mengaktifkan mereka. Masing-masing tim menggunakan teknik TQM yang telah 
mereka pelajari. Mereka menggunakan siklus Plan-DO-Check-Action sebagai model proses TQM.

b. Umpan Balik Kepada Steering Committee. Masing-masing tim memberikan informasi umpan balik dari pelanggan, baik pelanggan internal maupun eksternal. Survai formal pelanggan perlu dilakukan setiap tahun. Data yang diperoleh mengenai kepuasan pelanggan dikumpulkan dan diproses secara berkesinambungan.

c. Umpan balik dari Karyawan. Setiap tim yang berada dibawah kontrol SC secara periodik memantau sikap dan kepuasan karyawan yang ada dibawahnya. Kemudian mengadakan komunikasi ntensif dengan steering committee.

d. Memodifikasi Infrastruktur. Umpan balik yang diperoleh dari langkah-langkah di atas (dari tim proyek, pelanggan dan karyawan) akan dijadikan dasar oleh steering committee untuk melakukan perubahan yang diperlukan dalam infrastruktur lembaga pendiidkan.

Kemudian pada tataran praktis, implementasi dari konsep teoritis di atas dapat dikembangkan dalam konteks lembaga pendidikan. Kadang-kadang, terjadi kesulitan ketika menerapkan konsep TQM yang memang dari awalnya berasal dari dunia bisnis perusahaan. Oleh karena itu, Edward Sallis memberikan langkah-langkah yang sangat bermanfaat bagi pengelola pendidikan untuk dapat mengimplemantasikan konsep tersebut dalam sebuah lembaga pendidikan. Adapun langkah-langkahnya antara lain sebagai berikut: ${ }^{15}$

a. Kepemimpinan dan komitmen mutu harus datang dari atas. Seluruh tokoh mutu menekankan bahwa tanpa dukungan dari manajemen senior, maka sebuah inisiatif mutu tidak akan bertahan hidup. Kepala sekolah harus menunjukkan komitmen yang kuat dan selalu memotivasi supervisor lainnya agar selalu berupaya keras dan serius dalam meningkatkan mutu ini.

b. Menggembirakan pelanggan adalah tujuan TQM. Hal ini dapat dicapai dengan usaha yang terus-menerus untuk mencapai tujuan pelanggan, baik eksternal maupun internal. Kemudian pandangan dari oaring yang tidak bergabung di institusi juga dikumpulkan. Informasi dari konsultasi ini harus disusun dan di analisis kemudian digunakan ketika membuat keputusan.

c. Menunjuk fasilitator mutu. Fasilitator mutu harus menyampaikan perkembangan mutu langsung kepada kepala sekolah. Tanggung jawab fasilitator adalah mempublikasikan

${ }^{15}$ Edward Sallis, op.cit., h. 245-253. 
program dan memimpin kelompok pengendali mutu dalam mengembangkan program mutu.

d. Membentuk kelompok pengendali mutu. Kelompok ini harus merepresentasikan perhatian-perhatian kunci dan harus merupakan representasi dari tim manajemen senior. Perannya adalah untuk mengarahkan dan mendorong proses peningkatan mutu. Ia adalah pengembang ide sekaligus inisiator proyek.

e. Menunjuk koordinator mutu. Dalam setiap inisiatif dibutuhkan orang-orang yang memiliki waktu untuk melatih dan menasehati orang-orang lain. Koordinator tidak mengerjakan seluruh proyek mutu. Perannya adalah untuk membantu dan membimbing tim dalam menemukan cara baru dalam menangani dan memecahkan masalah.

f. Mengadakan seminar manajemen senior untuk mengevaluasi program. Pelatihan khusus dalam pendekatan strategis terhadap mutu mungkin dibutuhkan. Hal itu dikarenakan mereka perlu memberi contoh pada tim dalam memajukan institusi.

g. Menganalisa dan mendiagnosa situasi yang ada. Proses ini tidak bisa diremehkan, karena ia sangat menentukan seluruh proses mutu. Seluruh institusi perlu menjelaskan dimana posisinya dan mana arah yang mereka tuju.

h. Menggunakan contoh-contoh yang sudah berkembang di tempat lain. Ini bisa berupa adaptasi dari salah satu "guru" mutu atau seorang tokoh pendidikan khusus atau yang mengadaptasi pola TQM yang diterapkan di tempat lain untuk kemudian diambil sisi positifnya dan bisa diterapkan di sekolah yang dipimpin.

i. Mempekerjakan konsultan eksternal. Langkah ini sangat baik dilakukan, teruama jika ingin mencapai tingkat standar mutu internasional, semacam ISO. Akan tetapi biayanya cenderung mahal, hanya sekolah yang dengan sumber dana memadai yang bisa melakukan itu.

j. Memprakarsai pelatihan mutu bagi para staf. Pelatihan adalah tahap implementasi awal yang sangat penting. Oleh karena itu setiap orang perlu dilatih dasar-dasar TQM. Staf membutuhkan pengetahuan tentang beberapa alat kunci yang mencakup tim kerja, metode evaluasi, pemecahan masalah, dan teknik pembuatan keputusan.

k. Mengkomunikasikan pesan mutu. Strategi, relevansi dan keuntungan TQM harus dikomunikasikan secara efektif. Program jangka panjang harus dirancang seara jelas. Staf harus mendapatkan informasi atau laporan secara regular melalui surat kabar atau jurnal.

1. Mengukur biaya mutu. Mengetahui biaya dalam implementasi program mutu merupakan hal yang penting. Demikian juga dengan biaya pengabaian mutu. Biaya tersebut bisa 
muncul dari berkurangnya jumlah pendaftar, kegagalan murid, kerusakan reputasi dan sebagainya. Pengujian terhadap biaya pengabaian mutu itu juga perlu dilakukan, agar disatu sisi tetap berpegang pada program mutu, di sisi lain juga ada kontrol terhadap biaya yang dikeluarkan.

m. Mengevaluasi program dalam interval yang teratur. Evaluasi teratur harus menjadi bagian yang integral dalam program mutu. Evaluasi itu harus dilakukan eman bulan sekali secara teratur dan hasil dari evaluasi itu benar-bernar dijadikan bahan pertimbangan berjalannya program selanjutnya.

Untuk melaksanakan suatu manajemen mutu terpadu perlu ada sebuah strategi yang akan merancang operasionalisasinya. Proses perencanaan strategis dalam konteks pendidikan tidak jauh berbeda dengan apa yang biasanya digunakan dalam dunia industri dan komersial. Perencanaan strategis memungkinkan formulasi prioritas jangka panjang dan perubahan institusional berdasarkan pertimbangan rasional.

Sekolah harus mampu membuat analisis tentang perencanan strategis untuk selanjutnya menerapkan manajemen mutu terpadu (TQM) dalam dunia pendidikan dengan berbagai tantangan dan peluang yang ada harus mampu merumuskan perencanaan strategis untuk dapat menerapkan manajemen mutu yang baik dalam menghasilkan lulusan yang berkualitas yang berawal dari proses pendidikan yang bermutu.

\section{Kegagalan dalam Implementasi TQM}

Banyak lembaga pendidikan yang mampu menerapkan TQM, tetapi tidak sedikit pula yang gagal menerapkannya. Faktor-faktor yang menjadi penghalang bagi sekolah dalam menerapkan TQM. Hal-hal yang perlu dihindari karena dapat menggagalkan proses TQM adalah sebagai berikut: ${ }^{16}$

a. Kesenjangan komitmen manajemen puncak (kepala sekolah dan para wakilnya) sehingga tidak mampu pula membangun struktur organisasi yang diperlukan untuk pelaksanaan TQM serta tidak mampunya membentuk sistem hadiah (reward system) yang mendorong dilaksanakannya TQM.

b. Salah memfokuskan perhatian. Seharusnya semua langkah-langkah dalam TQM dilakukan secara urut dan lengkap. Karena semua bagaikan sistem yang saling mempengaruhi.

c. Tidak tersedianya karyawan yang memadai dan mendukung.

${ }^{16}$ Suyadi Prawirosentono, Filosofi Baru tentang Manajemen Mutu Terpadu Abad 21, (Jakarta: Bumi Aksara, 2007), h. 96-97. 
Keberhasilan TQM didasari oleh karyawan yang siap dan mempunyai komitmen akan tanggung jawab menjalani tugasnya pada manajemen mutu terpadu.

d. Hanya mengandalkan pelatihan semata-mata. Tanpa mementingkan bagaimana hasil pelatihan itu dilaksanakan (by action) seperti perbaikan mutu, menciptakan operasi yang lebih baik, jelas dan mengerti.

e. Harapan memperoleh sesaat, bukan hasil jangka panjang. Pelaksanaan TQM memerlukan perubahan organisasi secara menyeluruh dan budaya kerja. Perubahan tidak dapat segera terjadi dalam waktu singkat dan cepat, bahkan hasilnya mungkin baru dapat dirasakan satu sampai dengan dua tahun. Ketekukan dan kesabaran tim TQM di sini sangat diperlukan.

f. Memaksa mengadopsi suatu metode padahal tidak cocok. Tidak semua teknik dalam TQM cocok di berbagai lembaga. Hal ini perlu penyesuaian, bila tidak, hanyalah kegagalan yang diperoleh. Pimpinan sekolah perlu secara luwes dalam menerapkan sistem TQM, lalu mereka mempunyai kemauan untuk menelusuri kembali berbagai kekurangan secara tepat. Sehingga, dapat menentukan apakah sesuatu yang telah diadopsi itu cocok atau perlu penyesuaian dengan kondisi serta situasi sekolah atau perusahaan mereka.

Untuk mengantisipasi terjadinya kegagalan dalam implementasi Total Quality Management (TQM), maka sudah seharusnya terjalin kerjasama yang produktif, efektif dan efisien dalam mencapai tujuan yang telah ditetapkan sehingga peningkatan mutu pendidikan dapat tercapai.

\section{Kesimpulan}

Implementasi Total Quality Management (TQM) di lembaga pendidikan, yaitu: perbaikan secara terus menerus (continous improvement); menentukan Standar Mutu, (Quality assurance); perubahan kultur (change of culture); perubahan organisasi (upside-downorganization); dan mempertahankan hubungan dengan pelanggan (keeping close to the customer). Untuk menunjang implementasi TQM maka perlu strategi pelaksanaan yaitu Fase Persiapan, Fase Perencanaan dan Fase Pelaksanaan. Keberhasilan atau kegagalan implementasi TQM sangat bergantung pada komitmen dan kerja sama semua elemen lembaga pendidikan mulai dari manajemen puncak sampai di level staf. 


\section{Daftar Pustaka}

Abu-Duhou, Ibtasam., School Based Mangement, Manajemen Berbasis Sekolah, Jakarta: Logos, 2002.

Fatah, Nanang., Landasan Manajemen Pendidikan, Bandung: Remaja Rosdakarya, 2001.

Hardjosoedarmo, Soewarso., Total Quality Manajemen, Yogyakarta: Penerbit Andi, 2004.

Mulyasa, E.,Menjadi Kepala Sekolah Profesional, Cet. 9, Bandung: Remaja Rosdakarya, 2007.

Nasution, M.N. Manajemen Mutu Terpadu, Bogor: Ghalia IKAPI, 2005.

Prawirosentono, Suyadi., Filosofi Baru tentang Manajemen Mutu Terpadu Abad 21, Jakarta: Bumi Aksara, 2007.

Qomar, Mujamil., Kesadaran Pendidikan; Sebuah Penentu Keberhasilan Pendidikan, Yogyakarta: Arruzz Media, 2012.

Rivai, Veithrizal., Education Management; Analisis Teori dan Praktik, Jakarta: Raja Grafindo Persada: 2009.

Sallis, Edward., Total Quality Management in Education, Manajemen Mutu Pendidikan Jogjakarta: IRCiSoD, 2006.

Tim Gama Jakarta, Kamus Saku Ilmiah Populer, Jakarta: Gama Press, 2010.

Tjiptono, F. dan Anastasia Diana, Total Quality Management, Yogyakarta: Andi Offset, 2003.

http://guruidaman.blogspot.co.id/2014/06/total-quality-management-dalam.html 